Ritrýnd grein birt 26. september 2018

\title{
Áhrif Royaumont-málpingsins 1959 á íslenskt námsefni í stærðfræði fyrir börn
}

\author{
Kristín Bjarnadóttir
}

$\checkmark$ Abstract $\quad \rightarrow$ Um höfund About the author $\rightarrow$ Heimildir

Málping var haldið árið 1959 í Royaumont, Frakklandi, um nýja hugsun um skólastærðfræði. Royaumont-málpingið olli nokkrum straumhvörfum í hugsun um skólastærðfræði og rannsóknum á pví sviði. Nýjar hugmyndir um skólastærðfræði, sem ræddar voru par, voru nefndar nýja stærðfræðin, New Math, og tengdust hreyfingu, kenndri við Bourbaki, um endurskoðun á framsetningu stærðfræði með nútímalegum hætti, mathematique moderne. Í kjölfar málpingsins var tekið upp norrænt samstarf um greiningu á stöðu stærðfræðimenntunar á Norðurlöndum, námskrárgerð og samningu kennslubóka í tilraunaskyni. Stofnuð var nefnd, Nordiska kommittén för modernisering av matematikundervisningen, NKMM, sem stóð fyrir vinnu að verkinu á árunum 1960-1967.

Megináhersla norrænu nefndarinnar var á námsefni fyrir 7 -12. bekk og ætlunin var að efnið yrði hægt að pýða og staðfæra í hverju landi fyrir sig. Einnig voru ráðnir sérfræðingar um námsefni 1.-6. bekkjar. Danskur höfundur, Agnete Bundgaard, og finnsk samstarfskona hennar, Eeva Kyttä, voru ráđnar til að rita kennslubókaflokk fyrir tvö fyrstu árin frá sjö ára aldri og Agnete Bundgaard ritaði ein kennslubækur fyrir næstu fjögur aldursstig. Flokkurinn var pýddur á íslensku frá og með 1966.

Kennslubókaflokkur pessi, sem oft er nefndur Bundgaard-námsefnið, er greindur með tilliti til tillagna, sem settar voru fram á Royaumont-málpinginu um námsefni í stærðfræði fyrir barnaskóla, og borinn saman við eldra og yngra námsefni.

Niðurstöður sýna að áhrif tillagna, sem kynntar voru á málpinginu, um að leggja áherslu á formgerð talnakerfisins og setja efnið fram með hjálp mengjafræðilegra hugtaka, voru mikil en dvínuðu smám saman í síðari kennslubókum. Framsetning á tölum og talnakerfi byggðum á frumtölum og deilanleika gekk í endurnýjun lífdaga í íslenskri skólastærðfræði, ásamt nálgun (e. approximation) og mati (e. estimation). Enn fremur komu síðar fram nýir efnispættir sem ræddir voru í Royaumont, til dæmis tölfræði og líkindareikningur.

Efnisorð: Skólastærðfræði, Royaumont-málpingið, NKMM, Bundgaard-námsefni, Kennslubækur í stærðfræði 


\section{Inngangur}

Árið 1959 var haldið málping stærðfræðinga, stærðfræðikennara, fólks frá ráðuneytum menntamála og umsjónarmanna kennaramenntunar um nýja hugsun um skólastærðfræði. Málpingið var haldið á vegum OEEC í Royaumont, Frakklandi. Gerðar voru tillögur um róttækar breytingar á stærðfræðikennslu, par á meðal reikningi og algebru, jafnvel á fyrstu skólastigum. Í framhaldi var sett á laggirnar norræn nefnd um nútímavæðingu stærðfræðikennslu, Nordiska kommittén for modernisering af matematikundervisningen, skammstafað NKMM. Nefndin lét rita drög að námskrám og námsefni í stærðfræði sem síðan mætti pýða á ólík norræn tungumál. Meðal pess var námsefni, samið af Agnete Bundgaard og Eeva Kyttä, sem var pýtt á íslensku fyrir barnaskólastig (samsvarandi yngsta stigi og miðstigi í núverandi skólakerfi).

Hér á eftir eru metnar pær breytingar sem urðu á námsefni í reikningi fyrir barnaskóla á Íslandi fyrir áhrif Royaumont-málpingsins og kannað hverjar peirra festust í sessi. Inntak NKMM-námsefnisins fyrir barnaskólastig, Bundgaard-bókanna svonefndu, er greint með hliðsjón af tillögum sem komu fram á málpinginu í Royaumont og borið saman við efni eldri og yngri íslenskra kennslubóka til að draga fram áhrif málpingsins á íslenska reikningskennslu.

Reikniaðgerðirnar fjórar: samlagning, frádráttur, margföldun og deiling, voru og eru megininntak námsefnis í stærðfræði á barnaskólastigi samkvæmt lögum og námskrám. Með Bundgaard-bókunum bættust nýir námspættir við námsefnið sem nánar er gerð grein fyrir. Enn fremur voru notaðar aðrar aðferðir við uppsetningu reikningsdæma í Bundgaard-bókunum en notaðar höfðu verið í eldri kennslubókum. Dær ollu töluverðu umróti (Anna Kristjánsdóttir, 1996) en voru ekki til komnar fyrir áhrif Royaumont-málpingsins og eru ekki ræddar í pessari grein. Umræður á opinberum vettvangi á Íslandi um innleiðingu nýju stærðfræðinnar snerust að miklu leyti um nýju reikniaðferðirnar. Höfundur pessarar greinar hefur fjallað um umræðurnar í sérstakri grein (Kristín Bjarnadóttir, 2011).

Einnig hefur áður verið fjallað um menntapólitískar ástæður pess að farið var í námsefnisbreytingar (Kristín Bjarnadóttir, 2012). Dar er greint frá erlendum umbótahreyfingum á sviði stærðfræðikennslu og hvernig bergmál peirra barst til Íslands, fyrst og fremst fyrir persónuleg tengsl einstakra manna. Dar er gerð grein fyrir ferli innleiðingar nýs námsefnis á öllum skólastigum á Íslandi en einstakir námspættir ekki greindir eins og hér er gert. Enn fremur er ferli innleiðingarinnar á Íslandi borið par saman við pað sem gerðist í nágrannalöndunum Noregi og Danmörku.

Oft hefur verið spurt hvað hafi verið að eldri kennslubókum sem varð til pess að ráðist var í breytingar. Dví er til að svara að Reikningsbók eftir Elías Bjarnason (1927-1929; e.d.), sem pá var ein í boði fyrir reikningskennslu 9-12 ára barna, var orðin um fjögurra áratuga gömul að stofni til. Efni bókarinnar vísaði til pjóðfélags sem börn pekktu ekki (Kristín Bjarnadóttir, 2013). Endurnýjun pótti pví tímabær (Jónas B. Jónsson, munnleg heimild, 24. mars 2002).

Vandi innleiðingar á nýju efni fólst í pví að Bundgaard-kennslubækurnar, sem urðu fyrir valinu, voru aðeins tilbúnar í lokaútgáfu fyrir fyrsta árið og í drögum fyrir næstu tvö ár. Enginn vissi hvernig bækurnar mundu próast eftir að komið væri fram á fjórða námsár. Hugmyndum um breytingar var pó tekið fagnandi af skólastjórnendum á kynningu eftir fyrsta námsárið, 19661967. Dá hafði efnið verið kennt í sjö bekkjum í tveimur skólum í tilraunaskyni. Næsta skólaár var pað tekið upp í öllum bekkjum í mörgum skólum (Kristinn Gíslason, 1978).

Samkvæmt upplýsingum frá Menntamálaráđuneytinu, skólarannsóknadeild (1977), luku um 40\% árganga nemenda, sem fæddir voru á árunum 1962-1965, sex ára námi byggðu á nýju kennslubókunum. Allstór hluti næstu árganga á undan og eftir lásu einnig pessar kennslubækur. Gera má pví rád fyrir að um tíu púsund manns sem nú eru á sextugsaldri, fólk fætt á árunum 1959-1968, hafi notið kennslu samkvæmt Bundgaard-kennslubókunum og kynnst stærðfræðilegum hugtökum og orðaforða sem koma fram í rannsókninni sem hér er lýst. 


\section{Rannsóknin}

Farið verður yfir tillögur um reikningskennslu í hinni opinberu skýrslu um Royaumont-málpingið um nýja hugsun um stærðfræðimenntun (OEEC, 1961) og kannað að hve miklu leyti tillögurnar endurspeglast í kennslubókunum eftir Agnete Bundgaard og Eevu Kyttä fyrir barnaskólastig.

\section{Rannsóknarspurningar}

Spurt er

- hvaða hugmyndir um reikningskennslu, sem komu fram í skýrslu um málpingið í

Royaumont, voru innleiddar í námsefni sem samið var fyrir barnaskólastig á vegum

NKMM og kennt er við Bundgaard,

- hvort hugmyndirnar hafi verið nýjar á Íslandi og

- hvort pær hafi lifað af fyrstu hrifningarölduna í kjölfar breytinganna og hlotið varanlegan sess í íslenskri skólastærðfræði.

\section{Rannsóknargögn}

Kennslubókaflokkur NKMM fyrir 7-12 ára nemendur (Bundgaard og Kyttä, 1967-1968; Bundgaard, 1969a-1972) var pýddur á íslensku á árunum 1966-1971. Til samanburðar við hann eru greindir fjórir aðrir flokkar kennslubóka fyrir yngsta stig og miðstig með tilliti til atriða sem nefnd eru í framsögu um reikningskennslu og greint er frá í skýrslunni um málpingið í Royaumont (OEEC, 1961) og í niðurstöðukafla hennar. Bókaflokkarnir fimm eru:

- Reikningsbók I-IV eftir Sigurbjörn Á. Gíslason (1911), SÁG - 4 hefti

- Reikningsbók Elíasar Bjarnasonar (e.d.), EB - 3 hefti

- Stærðfræði - Reikningur 1, 2a, 2b, eftir Bundgaard og Kyttä (1967-1968) og 3a, 3b, 4a, 4b, 5a, 5b, 6, eftir Bundgaard (1969a-1972) - AB - 10 hefti

- Stærðfræði handa grunnskólum 1A-6B (Ragnhildur Bjarnadóttir o.fl., 1971-1977) - RB -14 hefti

- Stærðfræði fyrir byrjendur: kátt er í Kynjadal (Guðbjörg Pálsdóttir, 1998), Eining 1-6 (Mogensen og Balzer Petersen, 1999-2001), Geisli 1, 2, 3 (Guðbjörg Pálsdóttir, Guðný Helga Gunnarsdóttir, Guðrún Angantýsdóttir og Jónína Vala Kristinsdóttir, 2002-2004) GP - 11 hefti

Sumum pessara bókaflokka fylgja kennarabækur, vinnuhefti og fleira ítarefni. Dar sem könnuð var kynning efnisatriða einskorðaðist rannsóknin við grunnbækur sem samkvæmt framantöldu teljast vera alls 42 hefti.

Val á kennslubókum miðaðist við notkun á tímabilinu frá árinu 1911 fram til um 2010 eða um aldarlangt skeið. Fyrstu áratugi tímabilsins var völ á fleiri bókum en Reikningsbók Sigurbjörns Á. Gíslasonar (1911) en skólaskylda var pá fjögur ár frá tíu ára aldri samkvæmt págildandi lögum. Drír flokkar kennslubóka voru löggiltir fyrir íslenska barnaskóla árið 1929 (Helgi Elíasson, 1944, bls. 32): bókaflokkur $\underline{\text { SÁG }}$, eldri útgáfa af bókaflokknum EB (Elías Bjarnason, 1927-1929) og Reikningsbók handa alpýduskólum eftir Steingrím Arason (1928).

EB-flokkurinn í endurskoðaðri útgáfu var valinn til ókeypis dreifingar í skólum árið 1939 ásamt bók Steingríms Arasonar sem hvarf fljótlega úr dreifingu. EB-flokkurinn var pví næstum eingöngu í boði fram til 1967 (Kristín Bjarnadóttir, 2013). Síðar var ekki um annað að velja en bókaflokkana $\underline{\mathrm{EB}}, \underline{\mathrm{AB}}, \underline{\mathrm{RB}}$ og $\underline{\mathrm{GP}}$, hvern á tilteknum tímabilum sem pó gátu skarast um nokkra hríð. Bókaflokkarnir voru gefnir út af Ríkisútgáfu námsbóka og arftaka hennar, Námsgagnastofnun. 
Kennt var um reikniaðgerðirnar fjórar í heilum tölum, tugabrotum og almennum brotum í framangreindum bókaflokkum eins og kveðið var á um í gildandi lögum eða námskrám á hverjum tíma. Rannsóknin er athugun á pví til hvaða hugtaka og efnisatriða sem nefnd voru í Royaumont var gripið við framsetningu efnisins.

\section{Rannsóknaraðferð}

Tekin voru saman hugtök og efnispættir sem nefnd voru í framsöguerindi Gustave Choquet um reikningskennslu á barnaskólastigi og í niðurstöðukafla skýrslu um málpingið í Royaumont. Síðan var kannað hver peirra væri að finna í kennslubókaflokkunum fimm.

\section{Royaumont málpingið}

Málping um nýja hugsun um skólastærðfræði sem haldið var í nóvember 1959 markaði tímamót í sögu skólastærðfræði í heiminum. Рað er ævinlega kennt við fundarstaðinn, Royaumont í Frakklandi. Málpingið var haldið af hálfu Stofnunar um efnahagssamstarf Evrópuríkja, OEEC, Organisation for European Economic Co-operation, forvera Efnahags- og framfarastofnunarinnar, OECD, Organisation for Economic Co-operation and Development.

Fulltrúar allra aðildarlanda OEEC nema Portúgals, Spánar og Íslands sóttu málpingið (OEEC, 1961, bls. 213-220). Par hittust evrópskir og bandarískir forvígismenn hreyfinga um nýja skólastærðfræði, sem var nefnd vestanhafs New Math, ný stærðfræði.

Samtök um endurbætur á stærðfræðikennslu, Commission Internationale pour l'Étude et l'Amélioration de l'Enseignement des Mathématiques, CIEAEM (sjá vefsetur CIEAEM, e.d.) áttu einnig áberandi fulltrúa á málpinginu, par á meðal stærðfræðingana Gustave Choquet (1915-2006) og Jean Dieudonné (1906-1992) sem bádir voru frummælendur. Dieudonné var einn af forvígismönnum samtaka stærðfræðinga sem kenndu sig við Bourbaki og unnu að pví að setja alla pekkta stærðfræði fram með samræmdum rithætti og nefndu nútímalega stærðfræði, mathematique moderne. Meðal félaga í CIEAEM sem ekki sátu málpingið voru sálfræðingurinn og líffræðingurinn Jean Piaget (1896-1980) og stærðfræðingurinn Hans Freudenthal (1905-1990) (Furinghetti, Menghini, Arzarello og Giacardi, 2008).

Alls sátu málpingið 37 fulltrúar aðildarlanda. Tíu peirra voru stærðfræðingar við háskóla og prettán voru framhaldsskólakennarar. Séu prettán gestafyrirlesarar taldir með voru stærðfræðingar á málpinginu sextán og framhaldsskólakennarar sautján. Aðeins prír pátttakendur voru sérfræðingar á sviði kennaramenntunar og sjö voru frá ráðuneytum. Umræður snerust að miklu leyti um bilið milli háskólastærðfræði og stærðfræðikennslu í framhaldsskólum sem háskólakennarar, stærðfræðingarnir, töldu að brúa pyrfti (Schubring, 2014b).

Skýrsla um málpingið (OEEC, 1961) var gefin út tveimur árum síðar. Hún greinir misnákvæmlega frá pví sem par kom fram (Schubring, 2014a). Forseti málpingsins, Marshall Stone, sem var pá forseti alpjóðasamtaka um stærðfræðimenntun, International Commission on Mathematics Instruction, ICMI, hélt inngangserindi sem birt er í heild sinni í fyrsta kafla skýrslunnar. Stone lagði áherslu á að umbótastarfið pyrfti ekki síður að beinast að undirbúningi sérhæfðs iðnverkafólks en tilvonandi háskólastúdenta, verkfræðinga og vísindamanna. Hann vildi pannig stuðla að stærðfræðimenntun fyrir alla og kallaði eftir rækilegri greiningu á notkun grunnskólastærðfræði í nútímaiðnaði og daglegu lífi almennra borgara sem ætlast væri til að tækju pátt í kosningum og greiddu skatta. Stone lagði áherslu á að stærðfræði mætti ekki vekja andúð barna. Pað væri allt of augljóst að barnaskólunum mistækist að draga fram dulda stærðfræðihæfileika og áhuga venjulegra barna. Баð væri afar brýnt að ráđa bót á pessum vanköntum á stærðfræðikennslu barna. Sem betur færi bentu sálfræðilegar rannsóknir, sérstaklega af hálfu Jean Piaget, á uppeldisfræðilega möguleika sem hingað til hefðu verið ópekktir (OEEC, 1961, bls. 19-29). 
Dagskrá málpingsins var síðan skipt í prjá kafla: Um nýja hugsun um stærðfræði, um nýja hugsun um stærðfræðimenntun, og um pað hvernig hrinda mætti endurskoðun á skólastærðfræði i framkvæmd. Stærðfræðimenntun er rædd í priðja kafla. Par eru sett fram prjú menntunarmarkmið um skólastærðfræði sem:

a) pátt í almennri menntun

b) undirbúning undir líf og starf

c) undirbúning undir háskólamenntun.

Reikningskennsla væri grundvöllur að öllu frekara námi í stærðfræði. Gustave Choquet, prófessor í stærðfræði við Háskólann í París VI, ræddi hugmyndir um nýja hugsun í stærðfræðimenntun og lagði fram tillögur um nýja nálgun að kennslu í reikningi. Erindi hans var hið eina um reikningskennslu á barnaskólastigi. Рað er birt samandregið í priðja kafla skýrslunnar (OEEC, 1961, bls. 63-68).

Fimmti kafli skýrslunnar fjallar um samantekt og niðurstöður málpingsins (OEEC, 1961, bls. 105-125). Drátt fyrir hvatningu Stones til rannsókna og endurbóta á stærðfræðikennslu barna og fyrirætlanir hans um „stærðfræði fyrir alla“, hlaut málflutningur hans ekki stuðning 1 umræðum á málpinginu og lokaniðurstöðum (Schubring, 2014b).

Svend Bundgaard, prófessor í stærðfræði við Háskólann í Árósum, ræddi um stærðfræðilega hæfni kennara og menntun peirra en efni erindis hans er ekki getið í skýrslunni (Gert Schubring, tölvupóstur, 19. ágúst 2015). Svend Bundgaard er nefndur hér vegna tengsla hans við NKMM-námsefnið sem tekið var upp í barnaskólum á Íslandi og verður greint hér á eftir.

Minnispunktar voru teknir saman í lok fundarins. Skýrslan er ekki samhljóða peim, sumt hefur verið aukið en annað dregið saman. Niðurstöður um kennslu í reikningi sem greint er frá í skýrslunni eru pó samhljóða minnispunktunum í höfuðatriðum (OEEC, 1961, bls. 108-110; Schubring, 2014a, bls. 93-94).

Ýmsir hafa ritað um málpingið og áhrif pess, sem voru mikil. Oft er talið að paðan megi rekja upphafið аð stærðfræðimenntun sem fræðigrein. Furinghetti, Menghini, Arzarello og Giacardi (2008) rituðu ítarlega grein árið 2008 um ný viðfangsefni í stærðfræðimenntun í tilefni af 100 ára afmæli samtaka um stærðfræðimenntun, International Commission on Mathematics Instruction, ICMI. Meðal annarra sem hafa ritað nýlegar greinar eru Kilpatrick (2012), sem ritaði um alpjóðlegu hreyfinguna, og Prytz og Karlberg (2016) um atburði í Svípjóð. Kristín Bjarnadóttir (2017) hefur skrifað um áhrif málpingsins á námsefni fyrir barnaskóla á Norðurlöndum. Dessi grein fjallar um sama efni með ítarlegri hætti og með tilliti til íslensks samfélags.

\section{Norrænt samstarf}

Ein lokaályktana Royaumont-málpingsins var hvatning til pess að einstakar pjóðir tækju að endurskoða stærðfræðikennslu hjá sér í samræmi við aðstæður sínar og parfir en jafnframt var hvatt til sem mestrar samvinnu milli pjóða (OEEC, 1961, bls. 125). Norrænir pátttakendur á málpinginu ákváðu að efna til samstarfs. Hugmyndin var kynnt fyrir viðkomandi yfirvöldum og Norðurlandaráði, sem tók ákvörðun um að skipa nefnd, Nordiska kommittén för modernisering av matematikundervisningen, NKMM. Fjórir nefndarmenn voru tilnefndir frá hverju landanna fjögurra, Danmörku, Finnlandi, Noregi og Svípjóð. Nefndin var að störfum á árunum 19601967. Nefndarmenn voru stærðfræðikennarar í háskólum, framhaldsskólum og grunnskólum. Viðfangsefni nefndarinnar voru að greina stöðu stærðfræðimenntunar í hverju landi, setja fram drög að námskrám og endurskoða pau, og rita tilraunanámsefni fyrir námskeið á öllum skólastigum (Nordisk Råd, 1967b, bls. 16). 
Nefndin réð nokkra hópa höfunda til starfa. Megináherslan var á 7.-12. bekk. Ætlunin var að námsefni nefndarinnar yrði hægt að pýða og staðfæra í hverju landi fyrir sig (Gjone, 1983, II. bls. 78-80). Ritun hófst sumarið 1961 og nokkrir textar voru tilbúnir um haustið en aðrir síðar, allt fram til ársins 1966. Nefndin réð einnig sérfræðinga fyrir fyrsta til sjötta bekk. Fyrir valinu urðu Agnete Bundgaard, grunnskólakennari á Friðriksbergi í Kaupmannahöfn, systir Svends Bundgaard prófessors, frummælanda í Royaumont. Agnete og finnsk samstarfskona hennar, Eeva Kyttä, rituðu saman námsefni fyrir fyrsta og annan bekk, sjö og átta ára gamla nemendur, og Agnete ritaði síðan ein námsefni fyrir efri bekki að sjötta bekk meðtöldum. Hvorki Svíar né Norðmenn tóku Bundgaard-kennslubækurnar upp í barnaskólum. Norðmenn pýddu bandarískt efni í tilraunaskyni en notuðu að öðru leyti eldra efni. Svíar sömdu sitt eigið efni sem einnig var reynt í tilraunaskyni (Nordisk Råd, 1967a).

Danir voru meðal peirra pjóða sem gengu einna lengst í að færa hugmyndir Bourbaki-hópsins inn í háskólanámsefni í stærðfræði en einnig í námsefni framhaldsskóla. Hinn áhrifamikli Svend Bundgaard sagði er hann tók við prófessorsembætti við Háskólann í Árósum árið 1954: „Dessi nýja stærðfræði er nokkuð sem við verðum að taka inn í Danmörku. Við verðum að umbylta allri námsskipaninni og nútímavæða hana." Umbótahreyfingin hafði geysimikil áhrif í Danmörku (Karp, 2015). Ekki er ólíklegt að Svend Bundgaard hafi haft áhrif á ritun Agnete systur sinnar fyrir barnaskólastig.

\section{Viðtökur á Íslandi}

Guðmundur Arnlaugsson, stærðfræðikennari við Menntaskólann í Reykjavík, sem síðar varð rektor Menntaskólans við Hamrahlíð, var námsstjóri í stærðfræði við Menntamálaráðuneytið á árunum 1964-1966. Guðmundur hafði kynnst Svend Bundgaard á árunum 1933-1936 og 19391945 er hann var við nám og störf í Danmörku.

Vorið 1966 ræddu menn á vegum Fræðsluskrifstofu Reykjavíkur hvert skyldi stefna í umbótum á stærðfræðikennslu í barnaskólum Reykjavíkur (Kristinn Gíslason, 1978). Pá bar Guðmundur fregnir um námsefni NKMM, ritað af Agnete Bundgaard, sem Svend Bundgaard mun hafa sagt honum frá, en Íslendingar voru ekki aðilar að NKMM-samstarfinu. Gylfi P. Gíslason, sem var ráðherra menntamála og efnahagsmála á árunum 1956-1971, fylgdist vel með umsvifum OEEC, síðar OECD, á sviði menntamála. Hann sá til pess að endurskoðun yrði hafin á menntakerfinu, par með talinni stærðfræðikennslu. Hann treysti Guðmundi til að hafa forystu um breytingar á menntakerfinu, til dæmis í Menntaskólanum við Hamrahlíð, en hann hafði síðar efasemdir um nýju stærðfræðina (Gylfi P. Gíslason, munnleg heimild, 17. janúar 2002).

Degar var hafist handa við að pýða Bundgaard-bókaflokkinn sem pá hafði aðeins komið út í lokaútgáfu fyrir fyrsta bekk. Par var raunar lítill texti par sem gert var ráð fyrir að nemendur væru ólæsir er peir kæmu sjö ára í fyrsta bekk (Kristinn Gíslason, 1978; Kristín Bjarnadóttir, 2007, bls. 267-268). Námsefni síðari bekkja var mislangt komið í drögum og var pýtt jafnóðum og pað kom út í lokaútgáfu. Degar ákvörðun var tekin um námsefni NKMM var inntak pess pví ekki pekkt. Fjarlægð Íslands frá öðrum löndum og fjarvera pess frá norræna samstarfinu olli pví að íslenskir ráðamenn urðu að treysta pví sem pá leit út fyrir að horfa til framfara. Síðar kom í ljós að efnið var afar róttækt. Danski vísindasagnfræðingurinn Jens Høyrup (1979) mat Bundgaard-bókaflokkinn sem pað danska námsefni sem gengi lengst í pá átt að mæta kröfum stærðfræðinganna á Royaumont-málpinginu. 


\section{Reikningskennsla}

Reikningskennsla á rætur að rekja til loka miðalda er verslun og viðskipti tóku að vaxa í Evrópu. Farið var að prenta kennslubækur í reikningi á Ítalíu, í Portúgal, Dýskalandi og Hollandi á síðasta fjórðungi fimmtándu aldar. Reikniaðgerðirnar fjórar: samlagning, frádráttur, margföldun og deiling heilla talna og brotinna voru meginviðfangsefni reikningskennslunnar (Swetz, 1992; Van Egmond, 1980). Рað endurspeglast í lögum um fræðslu í reikningi á Íslandi árin 1880 og 1907 og í námskrá sem kom út árið 1929. Námsskrá fyrir nemendur á frođsluskyldualdri (Menntamálaráðuneytið, 1960) var í gildi er Bundgaard-bækurnar voru pýddar á íslensku. Í námskránni var gert ráð fyrir að kennt væri um reikniaðgerðirnar fjórar í heilum tölum, tugabrotum og almennum brotum. Aðeins var minnst á reikningspætti rúmfræði: flatarmál og rúmmál. Leiðbeiningar til kennara fylgdu og hvatt var til hugarreiknings. Bundgaard-bækurnar uppfylltu allar kröfur námskrárinnar. Í henni var pó gert ráð fyrir að nemendum væru kynnt almenn brot við 11 ára aldur en pau komu fyrst fram í Bundgaard-bókunum fyrir 12 ára nemendur.

Dáttur í hugmyndafræði hinnar nútímalegu stærðfræði Bourbaki-hópsins var að leysa upp mörk reiknings, algebru og rúmfræði. Áhersla var lögð á að draga fram frumsendur eins og gert hafði verið í árdaga fyrir rúmfræði í Frumpáttum Evklíðs (1956) frá pví um 300 f. Kr. Frumsendur talnareiknings og algebru mynda heildstæett kerfi um reiknieiginleika talna. Dær höfðu ádur birst í Kenslubók í algebru eftir Ólaf Daníelsson (1927) en aldrei í prentuðum íslenskum kennslubókum í reikningi. Frumsendur talnareiknings eru eftirfarandi, par sem bókstafirnir a, b, c tákna ótilteknar tölur:

\section{Samlagning}

$\begin{array}{lll}\text { R1. } & a+b \text { er ótvírætt ákvörðuð tala } & \text { [Lokun] } \\ \text { R2. } & (a+b)+c=a+(b+c) & \text { [Tengiregla] } \\ \text { R3. } & a+0=0+a=a & \text { [Hlutleysa] } \\ \text { R4. } & a+(-a)=(-a)+a=0 & \text { [Andhverfa] } \\ \text { R5. } & a+b=b+a & \text { [Víxlregla] }\end{array}$

\section{Margföldun}

$\begin{array}{lll}\text { R6. } & \mathrm{a} \cdot \mathrm{b} \text { er ótvíræett ákvörðuð tala } & \text { [Lokun] } \\ \text { R7. } & (\mathrm{a} \cdot \mathrm{b}) \cdot \mathrm{c}=\mathrm{a} \cdot(\mathrm{b} \cdot \mathrm{c}) & \text { [Tengiregla] } \\ \text { R8. } & \mathrm{a} \cdot 1=1 \cdot \mathrm{a}=\mathrm{a} & \text { [Hlutleysa] } \\ \text { R9. } & \mathrm{a} \cdot(1 / \mathrm{a})=(1 / \mathrm{a}) \cdot \mathrm{a}=1 & \text { [Andhverfa] } \\ \text { R10. } & \mathrm{a} \cdot \mathrm{b}=\mathrm{b} \cdot \mathrm{a} & \text { [Víxlregla] }\end{array}$

\section{Dreifiregla}

R11. $a \cdot(b+c)=a \cdot b+a \cdot c$

(Allendoerfer og Oakley, 1965, bls. 57)

Frummælendum á Royaumont-málpinginu varð tíðrætt um mikilvægi hugmynda Piagets um hugsanaferli ungra barna. Piaget hafði sagt að hluti af heild fæli í sér frumdrög að formgerð algebrunnar en hann rannsakaði tengsl milli formgerðar hugarstarfsins og stærðfræðilegrar formgerðar sem Bourbaki-hópurinn fékkst við. Hann setti niðurstöður sínar fram með stærðfræðilegu táknmáli eins og sjá má í grein hans frá árinu 1955 par sem hann talar um skynjun barna, yngri en sjö ára, á safni af tréperlum par sem B er heildarsafnið, A hluti pess og A' hinn hluti sama safns, gjarnan nefndur fyllimengi. Til pess að staðfesta að $\mathrm{A}<\mathrm{B}$ purfi barnið að átta sig á að $\mathrm{A}+$ $\mathrm{A}^{\prime}=\mathrm{B}$ eða $\mathrm{A}=\mathrm{B}-\mathrm{A}^{\prime}$ og $\mathrm{A}^{\prime}=\mathrm{B}-\mathrm{A}$. Hluti af heild leiði pannig til hugmyndar um algebrulega formgerd. Piaget setti fram frumsendur formgerðar sinnar: 
1. $A+A^{\prime}=B ; B+B^{\prime}=C ; C+C^{\prime}=D$; o.s.frv., par sem samheyrandi hlutar eru sundurlægir $\left(\mathrm{A} \times \mathrm{A}^{\prime}=0 ; \mathrm{B} \times \mathrm{B}^{\prime}=0\right.$; o.s.frv. $)$.

2. $-A-A^{\prime}=-B$, eða $A^{\prime}=B-A$; o.s.frv.

3. $\mathrm{A}-\mathrm{A}=0$.

4. $\mathrm{A}+\mathrm{A}=\mathrm{A}$ (klifun).

5. Tengiregla er takmörkuð við aðgerðir án klifunar: $\left(A+A^{\prime}\right)+B^{\prime}=A+\left(A^{\prime}+B^{\prime}\right)$, en $A+$ $(A-A) \neq(A+A)-A$

(Piaget, 1955, bls. 20, pýding höfundar).

Svo virðist sem stærðfræðingarnir í Royaumont hafi hrifist af pessari stærðfræðilegu framsetningu, en Hans Freudenthal, félagi í CIEAEM, sem sótti ekki málpingið í Royaumont, gagnrýndi fljótlega rannsóknir Piagets. Hann sagði pær athygli verðar en taldi varhugavert að tengja pær við stærðfræðinám par sem bakgrunnur Piagets í stærðfræði væri fremur veikur. Pá endurspegluðu rannsóknir Piagets varla aðstæður í kennslustofu heldur hinar óvenjulegu aðstæður í tilraunastofu sálfræðings (Furinghetti o.fl., 2008).

Piaget naut virðingar sem fræðimaður. Kenning hans um formgerð hugarstarfsins, par sem einföld hugmynd um hluta af heild er sett fram á flóknu táknmáli, virðist hafa leitt endurskoðun skólastærðfræði allt niður á fyrstu skólaár ólæsra barna til ótímabærrar áherslu á formgerð og táknmál.

\section{Tillögur frá Royaumont um reikningskennslu og framsetning í Bundgaard-bókaflokknum}

Priðji kafli Royaumont-skýrslunnar fjallaði um nýja hugsun í stærðfræðimenntun par sem leitað var svara við pví hvaða stærðfræði ætti að kenna, hverjum og hvernig. Gustave Choquet kynnti pann vanda sem við væri að etja á pessu sviði og ræddi sálfræðilegar skírskotanir í stærðfræðikennslu jafnframt efnisatriðum. Hér á eftir verða rakin efnisatriði á sviði mengjafræði, formgerðar talnakerfisins og talnafræði.

\section{Mengjafræðileg framsetning}

Í upphafi máls síns kynnti Choquet tilraunir Jeans Piaget um skilning barna á tölum og stærðum allt að sjö ára aldri (OEEC, 1961, bls. 62-63). Choquet ræddi síðan nútímalegu stærðfræðina, mathematique moderne. Dar væri ætlunin að leysa upp mörk milli reiknings, algebru, rúmfræði og örsmæðarreiknings. Ekki skyldi stilla reikningi og algebru upp sem andstæðum heldur flétta saman eins náið og unnt væri. Рað væri mögulegt með pví að íhuga hliðstæður í formgerð.

Mengin náttúrlegar tölur, $N$, og heilar tölur, $Z$, fælu í sér fjölda slíkra forma og par mætti draga fram atriði sem telja mætti hreina reiknieiginleika, svo sem deilanleika og frumtölur. Mengið $Z$ væri frábær grunnur að slíkri íhugun par sem svo virtist sem pað tæki mjög snemma á sig mynd í hugum barna. Hlutbundinn eiginleiki pess gerði pað ápreifanlegt svo að pað mætti nota til að kynna og rannsaka hugtök eins og gagnkvaema samsvörun (e. one-to-one correspondence), sem leiddi að hugtökunum fjöldatala (e. cardinal number), fall (e. function), umreikningur (e. conversion) og jafngildi (e. equivalence) (OEEC, 1961, bls. 63-64).

Dessi hugtök endurspeglast í efnisatriðum Bundgaard-bókaflokksins, sjá myndir 1, 2 og 3. Kennslubækurnar fyrir sjö og átta ára nemendur voru litprentaðar en kennslubækur fyrir eldri nemendur voru aðeins prentaðar í svarthvítu. 


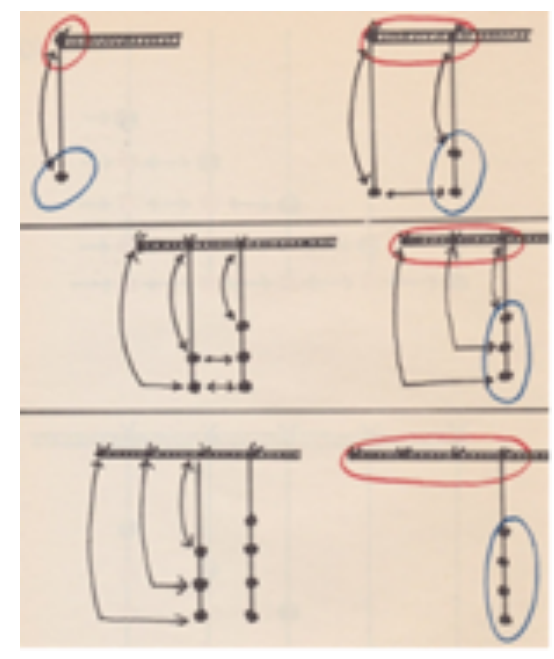

Mynd 1. Talnahugtakið byggt upp með gagnkvæmri samsvörun kúlna við talnalínuna sem er sýnd sem hnútaband. Fyrir sjö ára nemendur. (Bundgaard og Kyttä, 1967, 1, bls. 20).

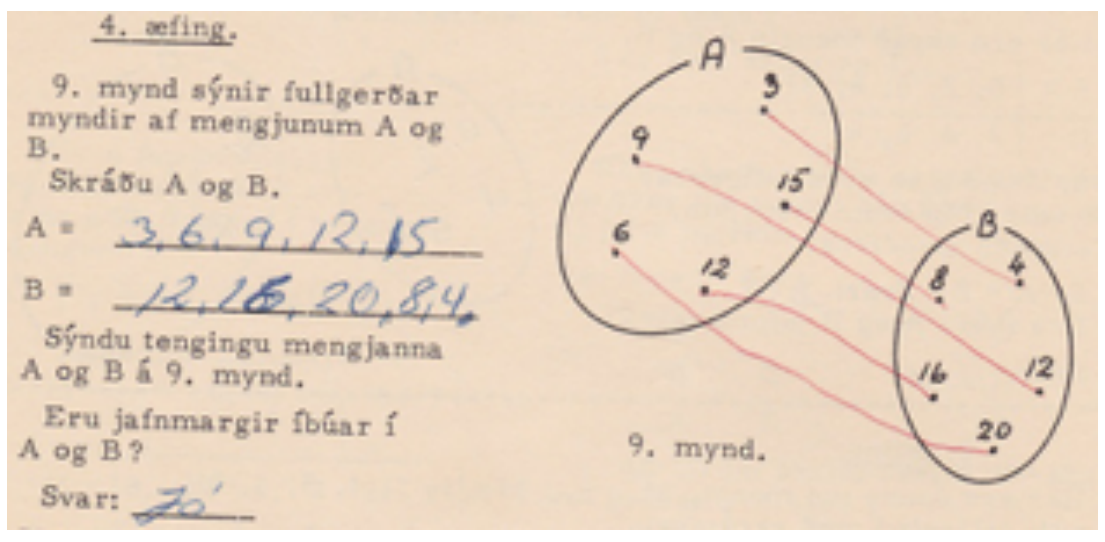

Mynd 2. Jafngildisvensl milli tveggja mengja. Fyrir tíu ára nemendur. (Bundgaard, 1970, 4a, bls. 24).*

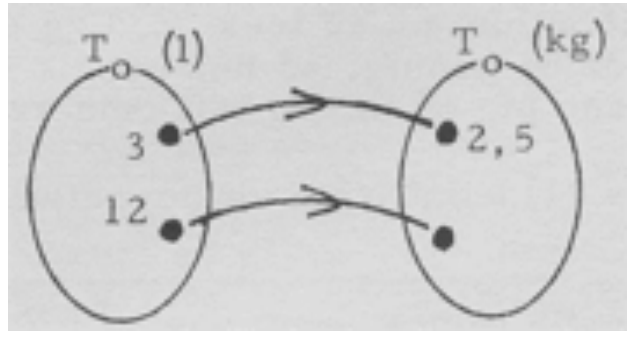

Mynd 3. Fallhugtakið par sem lítrar af olíu eru tengdir við vigt mælda í kg. Fyrir 11 ára nemendur. (Bundgaard, 1970, 4b, bls. 13).

Hvað varðaði reikningskennslu í barnaskólum væri hægt að sýna endanlegan fjölda fjöldatalna og raðtalna með Cuisenaire-kubbum, og samfara pví sagði Choquet að sýna mætti hugtökin hlutmengi úr mengi, fyllimengi, sammengi og sniðmengi tveggja eða priggja mengja. Hugtakið röðun mætti kanna með einföldum dæmum, sjá mynd 4 um framsetningu í Bundgaard-námsefninu. Dar má greina tengingu við hugmynd Piagets par sem hann sagði hluta af heild fela í sér undanfara að formgerð algebrunnar. 


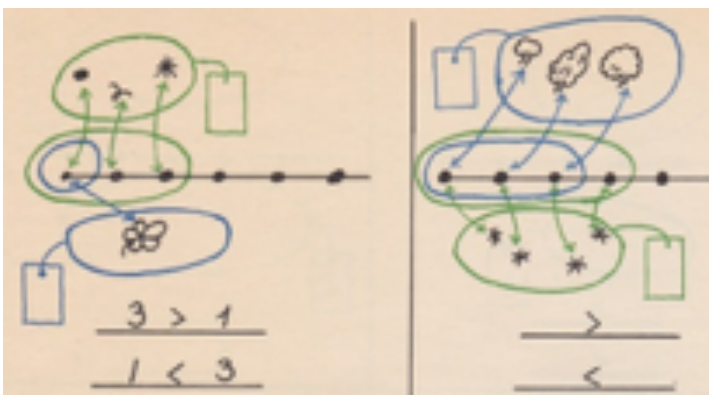

Mynd 4. Hlutmengi og röðun. Fyrir sjö ára. (Bundgaard og Kyttä, 1967, 1, bls. 29).

Sammengi og sniðmengi voru vandlega kynnt í báðum heftum Bundgaard-efnisins fyrir tíu ára nemendur. Dregnar voru fram frumsendur mengjaalgebru, líklega til að sýna hliðstæður við frumsendur talnareikningsins. Heiti frumsendna mengjaalgebru voru pó ekki nefnd.

Samlagningu og margföldun skyldi kynna sem sammengi sundurlagra endanlegra mengja og margföldun endanlegra mengja, sjá mynd 5 um samlagningu og mynd 6 um margföldun í Bundgaard-bókaflokknum.

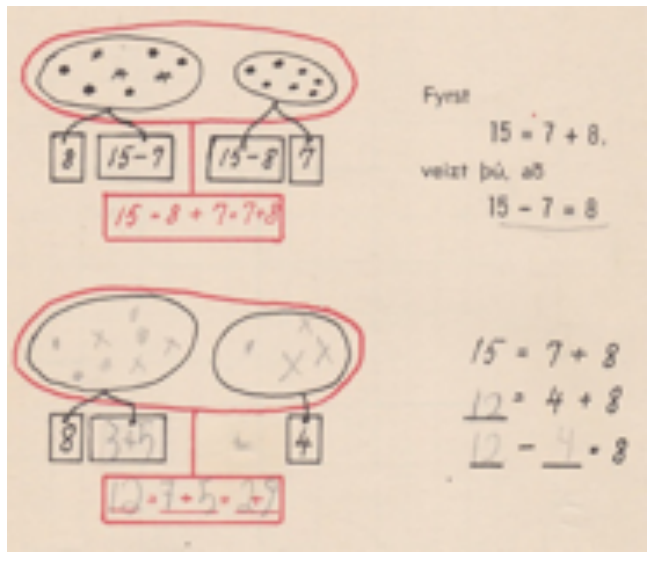

Mynd 5. Samlagning og frádráttur. Nemandinn sem vann verkefnið áttaði sig ekki alveg á hvernig bæri að fylla út í auðu reitina. Fyrir átta ára. (Bundgaard og Kyttä, 1968, 2a, bls. 20).^

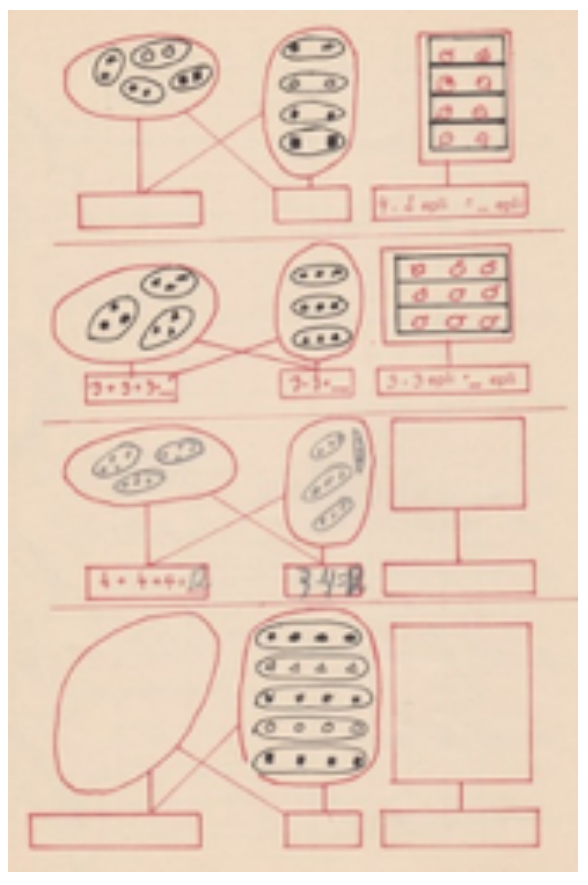

Mynd 6. Margföldun, epli talin. Nemandinn vissi að $3 \cdot 4=4 \cdot 3$. Fyrir átta ára. (Bundgaard og Kyttä, 1968, 2a, bls. 34).* 
Niðurstöðukafli skýrslunnar um Royaumont-námstefnuna fjallaði meðal annars um reikningskennslu. Par var rætt um að sálfræðilegir pættir [nýrra] námsaðferða í barnaskólum og tilfærsla markmiða skólastarfs í pá átt að próa hugtök og hugsunarmáta krefðust samsvarandi breytinga á reikningskennslu. Námið yrði að vera afrakstur skilnings sem sprytti af tilraunum undir leiðsögn og uppgötvunum, líklega með pví að nota einhvers konar ápreifanlega hluti. Dannig mætti leiða nemandann að peirri sértekningu eiginleika mengis sem nefnast tala. Leiðin að pessari sértekningu krefðist pess аð аð nota hugmyndir - en ekki nauðsynlega tungutak - um mengi, hlutmengi, gagnkvama samsvörun og rö̈un (OEEC, 1961, bls. 108-109).

Mengjafræðileg framsetning var einkum notuð í síðari kennslubókum við talningarfræðileg verkefni og flokkun, sjá til dæmis mynd 7 úr GP-námsefninu.

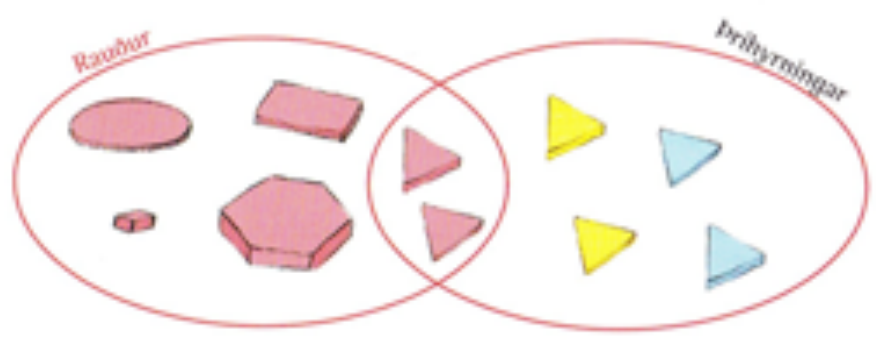

Mynd 7. Sammengi rauðra kubba og príhyrninga par sem rauðir príhyrningar eru í sniðmenginu. (Guðbjörg Pálsdóttir, Guðný Helga Gunnarsdóttir, Guðrún Angantýsdóttir og Jónína Vala Kristinsdóttir, 2003, 2, bls. 89).

Hér á eftir, í töflu 1, eru talin upp efnisatriði sem tengjast mengjafræði. Í töflum 1-3 eru tölur sem tákna aldursstigið pegar atriðið var fyrst sett fram. Aldur innan sviga merkir að atriðið var aðeins lauslega kynnt, lítið sem ekkert rökstutt og/eða ekki var unnið með pað í pví sem á eftir fór. Annars var reglulega komið að pví aftur.

Tafla 1. Mengjafræðileg hugtök í fimm íslenskum kennslubókaflokkum fyrir barnaskólastig

\begin{tabular}{|c|c|c|c|c|c|}
\hline Kennslubókaflokkar & SÁG & $\mathrm{EB}$ & $\mathrm{AB}$ & $\mathrm{RB}$ & GP \\
\hline Árabil í notkun & $1911-37$ & $1927-80$ & $1966-80$ & $1971-00$ & 1999-10 \\
\hline Aldursstig & $10-13$ & $10-12$ & $7-12$ & $7-12$ & $6-12$ \\
\hline Mengi & & & 7 & 7 & 10 \\
\hline Gagnkvæm samsvörun & & & 7 & (7) & \\
\hline Hlutmengi & & & 7 & 7 & \\
\hline Sammengi & & & (7), 10 & & 11 \\
\hline Sniðmengi & & & 10 & & 11 \\
\hline Inngangur að mengjaalgebru & & & 10 & & \\
\hline Mengjamismunur & & & 10 & & \\
\hline Fyllimengi & & & 10 & & \\
\hline Táknmál mengjafræði & & & 10 & (11) & \\
\hline
\end{tabular}


Af töflu 1 má lesa að mengjafræðileg hugtök voru ópekkt fyrir tilkomu Bundgaard- kennslubókanna og notkun peirra dvínaði hratt í síðari kennslubókum. Deim brá par pó fyrir síðar en ekki jafnkerfisbundið og í Bundgaard-kennslubókunum í pví skyni að draga fram stærðfræðileg hugtök. Mengi sett fram sem hringlaga myndir komu til dæmis aðallega fyrir í RB-bókaflokknum fyrir yngstu aldursflokkana en voru síðar sett fram sem upptalning í svigum. Sammengi og sniðmengi voru ekki nefnd í RB-bókaflokknum en birtust á eðlilegan hátt í talningarfræðilegum verkefnum í GP-bókaflokknum til hagræðis við að setja slík verkefni fram á myndrænan hátt.

Aðeins hefur verið fjallað um hugtök nýju stærðfræðinnar en hugtökunum fylgdi táknmál. Mynd 8 sýnir blaðsíðu úr Bundgaard-kennslubók, hefti $\mathbf{5 b}$, fyrir 11 ára nemendur, par sem dregið er saman táknmál mengjafræðinnar sem kynnt var í fyrri heftum.

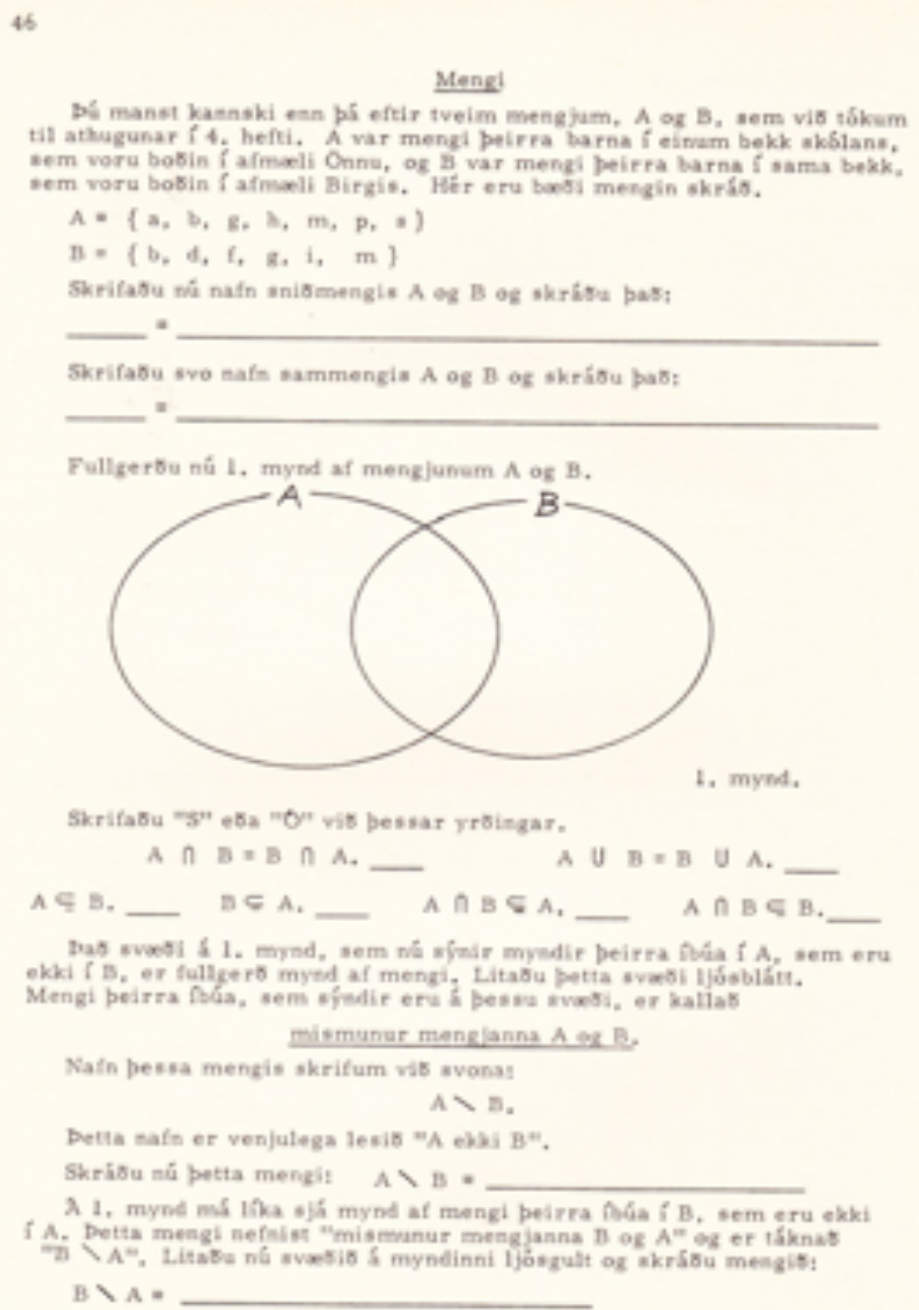

\section{Formgerð talnakerfisins og frumsendur talnareiknings}

Í niðurstöðukafla skýrslunnar um Royaumont-námstefnuna sagði að nauðsynlegur páttur í byrjendakennslunni væri að stuðla að skilningi á sætiskerfi talna og notkun pess. Ásamt pví að efla tilfinningu fyrir frumsendum talnareiknings: víxlreglu, tengireglu og dreifireglu, væri hægt að próa aðgerðir á heilum tölum, almennum brotum og tugabrotum á skynsamlegan hátt án neinna brellna (OEEC, 1961, bls. 108-109). 
Frumsendur talnareiknings voru kynntar skref fyrir skref í Bundgaard-bókaflokknum. Kynningin hófst á víxlreglu samlagningar í fyrsta heftinu fyrir sjö ára gamla nemendur, sjá mynd 9, eftir að röðun hafði verið kynnt, sjá mynd 4.

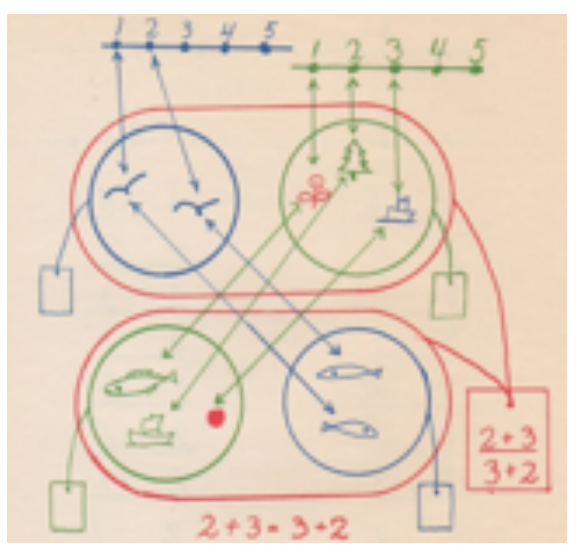

Mynd 9. Víxlregla. Fyrsta kynning á samlagningu og „+“ tákninu. Fyrir sjö ára. (Bundgaard og Kyttä, 1967, 1, bls. 32).

Víxlreglu var fylgt eftir með tengireglu samlagningar síðar í fyrsta bekk, sjá mynd 10.

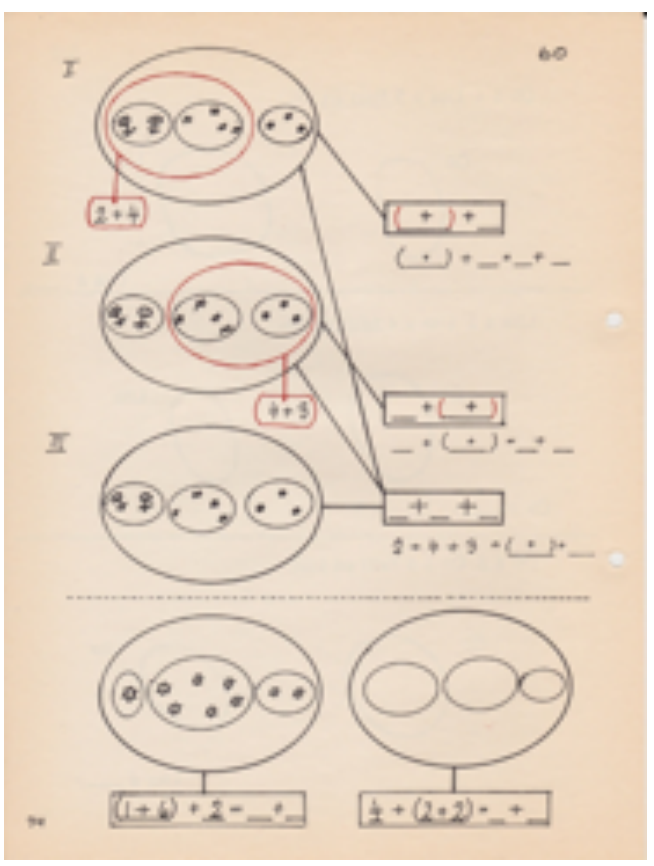

Mynd 10. Tengiregla samlagningar. Fyrir sjö ára. (Bundgaard og Kyttä, 1967, 1, bls. 74).

Myndir 11 og 12, sem sýna dreifireglu, eru einu myndirnar af daglegu lífi fólks í bókaflokknum. Agnete Bundgaard tók skýrt fram að hún vildi ekki dreifa huga nemenda með myndum sem ekki tengdust námsefninu. Hún sagði í bréfi til íslenskra kennara: „Kære islandske kolleger. Det er Dem, der skal pröve at vise börnene, at faget i sig selv er morsomt og til dette formål kan jo kun benyttes ting som er relevante for faget." (Bundgaard, 1969b, bréf sem fylgdi Handbók kennara, 3. hefti). 


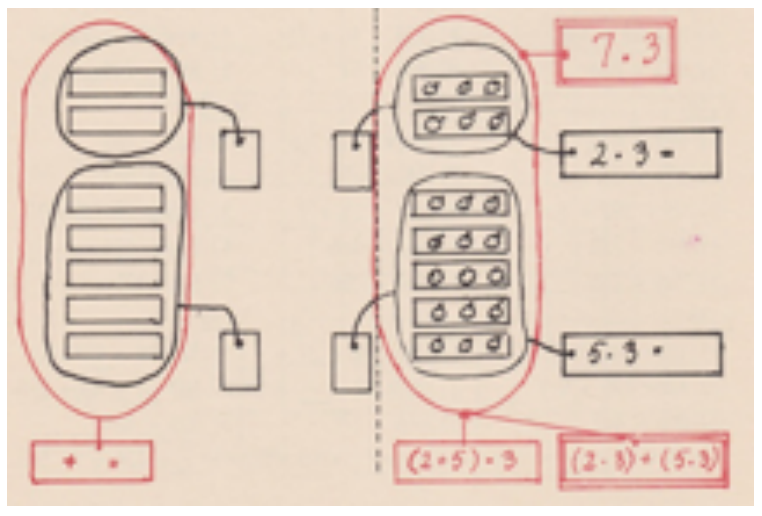

Myndir 11 og 12. Dreifiregla. Fyrir átta ára. (Bundgaard og Kyttä, 1968, 2b, bls. 72).

Kynning á frumsendum talnakerfisins er dregin saman í töflu 2. Víxlreglur og tengireglur samlagningar og margföldunar voru kynntar hver á eftir annarri við sjö ára aldur í Bundgaard-námsefninu, par sem heiti reglnanna voru skýrt tekin fram. Hlutleysur samlagningar og margföldunar voru kynntar við níu ára aldurinn. Margföldunarandhverfa var sett fram í tengslum við deilingu við 12 ára aldur. Samlagningarandhverfa var ekki tekin fyrir par sem neikvæðar tölur komu ekki fyrir í bókaflokknum. Andhverfar aðgerðir koma fram í GP-bókaflokknum og eru teknar hér með vegna skyldleika peirra við samlagningar- og margföldunarandhverfur.

Tafla 2. Frumsendur um talnareikning í Bundgaard-bókaflokknum í samanburði við aðra bókaflokka.

\begin{tabular}{llllll}
\hline Kennslubókaflokkar & SÁG & EB & AB & RB & GP \\
\hline Árabil í notkun & $1911-37$ & $1927-80$ & $1966-80$ & $1971-00$ & $1999-10$ \\
Aldursstig & $10-13$ & $10-12$ & $7-12$ & $7-12$ & $6-12$ \\
Víxlregla samlagningar & & & 7 & 7 & 11 \\
Víxlregla margföldunar & $(10)$ & & 8 & 10 & 11 \\
Dreifiregla & & 8 & 10 & 11 \\
Tengiregla samlagningar & & 7 & & 11 \\
Tengiregla margföldunar & & 9 & 12 & 11 \\
Hlutleysa samlagningar & & 9 & & 12 \\
Hlutleysa margföldunar & & 9 & & 12 \\
Samlagningarandhverfa & & & & & \\
Margföldunarandhverfa & & & & & 12 \\
Andhverfar aðgerðir & & & & & 11 \\
- samlagning - frádráttur & & & & & \\
- margföldun - deiling & & & & & \\
\hline
\end{tabular}

Grundvallarreglur talnareiknings sem felast 1 frumsendunum eru nauðsynlegar undirstöður reiknings. Fyrr á tímum var kennurum falið að koma peim til skila án pess að peim væri gefið heiti. Lögð var mikil áhersla á pað í Bundgaard-bókaflokknum að nemendur beittu reglunum meðvitað og nefndu pær með sínu heiti. Af töflu 2 má lesa að haldið var áfram eftir að Bundgaard-bækurnar voru lagðar af að nefna heitin, einkum víxlreglu, tengireglu og dreifireglu. 


\section{Tölur og talnavensl}

Choquet taldi að kynning á jákvæðum og neikvœðum heiltölum frá níu ára aldri ylli engum vandkvæðum. Nota mætti færslur til hægri og vinstri. Detta efni mætti líka æfa í leikjum, t.d. með vinningi og tapi. Баð veitti betri skilning á núlli og gæti hentað sem inngangur að algebru. Níu-prófun ${ }^{1}$, sem erfitt er að rökstyðja á pessu stigi, ætti að hverfa. Nemendur ættu fremur að prófa reikninga sína með pví að snúa peim við og nota andhverfa aðgerð, prófa samlagningu með frádrætti og öfugt.

Tugabrot ætti að innleiða fremur snemma, einskorðuð við hentugan rithátt til að skrá stórar tölur en ekki til að rannsaka eiginleika reikningsaðgerða. Margföldun og deiling stórra talna væru óparfa byrðar fyrir börn. Pau pyrftu að kunna einfaldan og fljótvirkan hugarreikning og pjálfast 1 nálgun (e. approximation) og mati (e. estimation) á stórum tölum (OEEC, 1961, bls. 65).

Ekki væri hægt að komast hjá almennum brotum, sem væru mesta hindrunin í reikningskennslu, en á barnaskólastigi ætti ekki að líta á brot sem tölur eins og í reikningsdæminu $2 / 3+1 / 5$. Líta ætti á brotin sem „,virkja“ (e. operator) sem verkaði á stærðir, til dæmis að finna $2 / 3$ af stærð. Síðar, pegar mengi rauntalna hefði verið kynnt sem ,arkimedískt raðað víxlið talnasvið“, yrði engin spurning um brot par sem samkvæmt skilgreiningu yrði brot eins og $2 / 3$ stak í pví. Ólík brot táknuðu sama virkja, s.s. $2 / 3$ og 4/6. Par af stafaði ruglingur milli virkja og brota sem talna og par af spryttu erfiðleikar við að skilgreina summu og margfeldi brota (OEEC, 1961, bls. 66).

Segja má að stærðfræðingarnir í Royaumont hafi farið fram úr sér með pví að nefna ,,arkimedískt raðað víxlið talnasvið“. Dað er sérstakur kimi hreinnar algebru á háskólastigi og hefur aldrei verið páttur í skólastærðfræði. En stærðfræðingarnir hafa áttað sig á erfiðleikunum við brotareikning sem hefur löngum reynst mörgum nemendum fjötur um fót. Áhugavert hefði verið að sjá nánari umræður um pað efni.

Í niðurstöðukafla skýrslunnar sagði að skýrum börnum mætti kynna talnavensl, svo sem oddatölur og sléttar tölur, frumtölur, páttun, storsta sameiginlega pátt, minnsta sameiginlega margfeldi og satiskerfi önnur en tugakerfi. Síðar mætti minnast á tölfrreðileg meðaltöl, mátkerfi (e. modular systems), talnarunur o.fl. Slíkt yrði vissulega að vera í umsjón kennara sem skildi öll undirliggjandi stærðfræðileg vensl og tengsl efnisins við eftirfarandi námsefni (OEEC, 1961, bls. 109-110).

Einnig var minnst á atriði sem pátttakendur voru ekki sammála um, svo sem hvort kynna ætti snemma neikveæðar tölur sem viðbót eða fylgiafurð heilla jákvæðra talna og brota, hvort kenna skyldi að draga rót ádur en töflur væru notaðar, og hvort nota mætti stæður eins og $8+1,7+2$, ... sem annað heiti á 9, eða líta fremur á pær sem aðgerð.

Önnur atriði, sem ekki var eining um, voru notkun reiknivéla og að hve miklu leyti skyldi nota kubba og liti. Á hinn bóginn var eining um að kenna skyldi reikning pannig að formgerðin kæmi skýrt fram, að leggja áherslu á frumsendurnar og á hlutverk talnanna 0 og 1 . Allt sem kennt væri ætti að pjóna sem undirbúningur fyrir frekara nám en á barnaskólastigi væri pað gert óbeint. Ekki var tími til að ræða hvernig víkka mætti út reikning til ræðra talna og rauntalna (OEEC, 1961, bls. 110).

Níupróf var algengt áður fyrr pegar purfti til dæmis að leggja saman margar tölur. Pá var deilt í hvern lið samlagningarinnar með níu, afgangar deilinganna lagðir saman og deilt í pá summu með níu. Afgangur peirrar deilingar átti pá að vera hinn sami og afgangurinn pegar deilt var í heildarsummuna með níu. Prófið er pó ekki einhlítt. Pað er dæmi um hagnýtingu mátreikninga. 
Tafla 3. Tölur og talnavensl í Bundgaard-bókaflokknum í samanburði við aðra bókaflokka.

\begin{tabular}{|c|c|c|c|c|c|}
\hline Kennslubókaflokkar & SÁG & EB & $\mathbf{A B}$ & $\mathbf{R B}$ & GP \\
\hline Árabil í notkun & $1911-37$ & $1927-80$ & $1966-80$ & $1971-00$ & 1999-10 \\
\hline Aldursstig & $10-13$ & $10-12$ & $7-12$ & $7-12$ & $6-12$ \\
\hline \multicolumn{6}{|l|}{ Almenn brot: } \\
\hline - sem virkjar & 11 & 11 & 12 & 9 & 10 \\
\hline - aðgerðir & 12 & 11 & 12 & 9 & 11 \\
\hline Neikvæðar tölur & & & & 11 & 9 \\
\hline Tugabrot & 12 & 11 & 10 & 11 & 10 \\
\hline Talnalínan & & & 7 & 7 & 6 \\
\hline \multicolumn{6}{|l|}{ Talnavensl: } \\
\hline sléttar tölur og oddatölur & 13 & 11 & 8 & 8 & 8 \\
\hline frumtölur & 13 & & 9 & 12 & 12 \\
\hline Frumpáttun & 13 & & 10 & 12 & 12 \\
\hline Deilanleiki & 13 & $(12)$ & 9 & & 12 \\
\hline 0 í margföldun & $(11)$ & & 8 & & 10 \\
\hline 0 í deilingu & & & 10 & & \\
\hline Önnur sætiskerfi en tugakerfi & & & 9 & & \\
\hline Mátkerfi (e. modular systems) & & & 11 & & \\
\hline Tákn eins og $7+2$ fyrir 9 & & & 8 & 7 & 8 \\
\hline Níu-próf & & & 11 & & \\
\hline \multicolumn{6}{|l|}{ Breytur } \\
\hline - staðgenglar tiltekinna talna & & & & 7 & 10 \\
\hline - stærðir með breytileg gildi & & & & & 11 \\
\hline Jöfnur & & & & 10 & 10 \\
\hline Inngangur að líkindareikningi & & & & 9 & 10 \\
\hline Inngangur að tölfræði & & & 11 & 8 & 10 \\
\hline Hugarreikningur & 10 & & 8 & 9 & 6 \\
\hline Nálgun, mat & & & 11 & 8 & 9 \\
\hline Notkun vasareikna & & & & & 10 \\
\hline
\end{tabular}

Tafla 3 sýnir að neikvœðar tölur voru ekki teknar fyrir í Bundgaard-efninu og heldur ekki í eldri bókaflokkum fyrir barnaskólastig. Yngri bókaflokkar kynntu neikvæðar tölur: $\underline{\text { RB }}$ við ellefu ára aldur og GP við níu ára aldur. Pessari rannsókn er aðeins ætlað að gera grein fyrir pví hvenær hugtök voru kynnt en ekki hvenær vandasamar reikniaðgerðir eins og margföldun tveggja neikvæðra talna voru teknar fyrir. Choquet nefndi að almenn brot væru mesta hindrunin í reikningskennslu og sagði að hann hefði pá átt við reikniaðgerðir almennra brota. Hvenær pær skyldu teknar fyrir og með hvaða hætti er ekki nefnt í Royaumont-skýrslunni. 
Efnispæettir um tölur, svo sem frumtölur og deilanleiki, gengu í endurnýjun lífdaga í Bundgaardbókaflokknum eftir að hafa verið áberandi í bókaflokki Sigurbjarnar Á. Gíslasonar, SÁG, í byrjun 20. aldar. Sætiskerfi önnur en tugakerfi, til dæmis fimmundakerfi, ferundakerfi og tylftakerfi, sem kynnt voru í priðja bekk (Bundgaard, 1969a, 3b, bls. 86-92), vöktu athygli en komu ekki fyrir í síðari bókaflokkum fyrir yngsta stig og miðstig. Hið sama má segja um mátreikninga (e. modular arithmetic), par sem reiknað er innan takmarkaðs talnamengis eins og til dæmis á klukkunni par sem talið er innan mengisins 1 til 12 eða 1 til 24. Hins vegar komu efnispæettirnir nálgun (e. approximation) og mat (e. estimation) inn í Bundgaard-bókaflokknum, $\underline{\mathrm{AB}}$, og héldu velli eftir pað. Mælt var með pví í Royaumont-skýrslunni að líkindareikningur og tölfreðð, sem birtust í síðari kennslubókaflokkum fyrir barnaskólastig, yrðu sett fram á unglingastigi (OEEC, 1961, bls. 106-107) og tölfræðilegum meðaltölum brá fyrir í Bundgaard-bókaflokknum. Einfaldar jöfnur og breytur fóru líka að koma snemma fram í síðari bókaflokkum.

\section{Niðurstöður}

Spurt var hvaða hugmyndir um reikningskennslu, sem komu fram í Royaumont, voru innleiddar í námsefni sem samið var fyrir barnaskólastig á vegum NKMM. Hér að framan hefur verið rakið hvernig Bundgaard-kennslubækurnar voru sniðnar að hugmyndum sem fram komu í skýrslunni um Royaumont-fundinn. Par sagði að leiðin að uppbyggingu talnahugtaksins krefðist pess að nota hugmyndir um mengi, hlutmengi, gagnkvæma samsvörun og röðun. Dví var vissulega beitt í Bundgaard-efninu og ekki aðeins hugmyndum heldur var einnig lögð áhersla á táknmál mengjafræðinnar, sjá töflu 1.

Frumsendunum víxlreglu, tengireglu og dreifireglu var óspart beitt til að próa aðgerðir á heilum tölum, almennum brotum og tugabrotum á rökstuddan hátt og draga fram formgerð talnakerfisins, sjá töflu 2. Frumsendurnar voru skýrt dregnar fram með heitum og reglulega minnt á formgerðina. Rík áhersla var einnig lögð á að efla talnaskilning, til dæmis með páttun og deilanleika, og skilning á sætiskerfi talna,.

Einnig var spurt hvort hugmyndirnar frá Royaumont hefðu verið nýjar á Íslandi. Dví er til að svara að nýir efnispættir í Bundgaard-bókaflokknum í samanburði við fyrra efni voru í fyrsta lagi mengjafræðileg hugtök og táknmál mengjafræðinnar. Talnahugtakið og talnakerfið voru skipulega byggð upp allt að neikvæðum tölum út frá mengjafræðilegum forsendum í Bundgaard-námsefninu.

Í öðru lagi var leitast við að efla skilning á talnahugtakinu og reikniaðgerðum með endurteknum tilvísunum til frumsendna talnareiknings. Ekki hafði tíðkast áður að nefna frumsendurnar berum orðum en pó hafði vissulega verið dregið fram í eldra námsefni með endurteknum æfingum аð $3+5$ væri jafnt $5+3$ og $5 \cdot 7=7 \cdot 5$ svo að dæmi séu tekin. Dessar reglur voru sjaldnast ræddar í kennslubókum heldur eftirlátið kennurunum. SÁG nefndi pó víxlreglu lítillega. Síðari kennslubækur, bæði Stærðfræði handa grunnskólum, RB, og Geisli, GP, nefna vissulega frumsendurnar en par voru pær fremur nýttar til að styðja við reikniaðgerðir en til að draga fram formgerð talnakerfisins.

Að lokum var spurt hvort hugmyndir stærðfræðinganna í Royaumont hefðu lifað af fyrstu hrifningarölduna í kjölfar breytinganna og hlotið varanlegan sess í íslenskri skólastærðfræði. Fljótlega dró verulega úr mengjafræðilegri framsetningu og minna var leitast við að draga fram formgerð talnakerfisins í síðara námsefni. Líta verður svo á að kennarar sem tóku til við að semja nýtt námsefni i kjölfar Bundgaard-bókaflokksins hafi ekki talið mengjafræðina og formgerðina stuðla аð peim aukna skilningi sem peim var ætlað.

Meðal pess sem hefur lifað fram á pennan dag í skólastærðfræði barna er samsetning náttúrlegra talna úr frumtölum, deilanleiki og áhersla á hugarreikning. Dessar hugmyndir voru pó engan veginn nýjar heldur má til dæmis rekja hugtökin frumtölur og frumpáttun aftur til Forn-Grikkja. Frumtölur, frumpáttun og hugarreikningur áttu líka góðan sess í bókaflokki SÁG en 
lágu í láginni á hinu langa skeiði er bókaflokkur Elíasar Bjarnasonar, EB, var nær einn í boði í skólakerfinu. Nálgun og mat hafa líka öðlast fastan sess í skólastærðfræði á Íslandi og sömuleiðis notkun reiknivéla en á pví sviði voru Royaumont-menn framsýnir.

Inngangur að tölfræði og líkindareikningi hefur komið í stað pess sem ekki hefur fest í sessi. Dessir efnispættir voru ræddir í Royaumont en síður ætlaðir barnaskólastigi. Hið sama má segja um notkun breytistærða og lausn einfaldra jafna.

Ekki er hægt að segja að neitt af pví sem var að finna í bókum Elíasar Bjarnasonar hafi horfið. Dar voru kenndar aðferðir við reikniaðgerðirnar fjórar í heilum jákvæðum tölum, tugabrotum og almennum brotum í samræmi við námskrá frá 1960 og eldri námskrá og lög. Aðferðirnar voru vissulega öðruvísi en í Bundgaard-bókaflokknum, en lítið var rætt við nemendur eða færð fram rök, aðeins fyrirmæli um hvernig fara skyldi að.

Varla er hægt að segja að Bundgaard-bókaflokkurinn hafi stutt við tilrauna- eða uppgötvunarnám. Dvert á móti var lögð áhersla á hugtök um formgerð, mengjamálfar og tilheyrandi táknmál. Á hinn bóginn var lögð sérstök rækt við athuganir á talnavenslum og sætisrithátt í tugakerfi. Nokkur áhersla var á að nota mætti stæður eins og $8+1$ og $7+2$ fyrir tölur, sjá töflu 3. Slíkar stæður voru nefndar plúsheiti tölunnar. Pau voru gjarnan notuð til að hluta tölur niður í tugi og einingar, svo sem $14=10+4$ til að styðja við skilning á pví að geyma í samlagningu, eða til að örva hugarreikning með hjálp tengireglu, til dæmis: $13+9=13+(7+2)=(13+7)+2=20$ $+2=22$.

\section{Umræða}

Rétt er að nefna að samanburður eins og hér hefur verið lýst gefur aðeins yfirborðskennda mynd af framsetningu námsefnisins í kennslubókunum. Aðeins er getið um hugtök en ekki er nánar kynnt hvernig pau eru sett fram. Rannsóknaraðferðin er ekki hönnuð til pess. Veigamikill páttur í pví að Bundgaard-námsefnið olli miklu uppnámi á Íslandi var að par voru kynntar aðrar aðferðir og önnur uppsetning við samlagningu, frádrátt, margföldun og deilingu en tíðkast hafði um langa hríð. Var pað kallað mengjareikningur pótt uppsetning reikningsdæmanna hafi ekki stuðst við mengjaframsetningu. Áhugavert væri að gera peim aðferðum skil í sérstakri grein. En vonast er til að pessi grein verði til að vekja áhuga almennings, kennara, höfunda kennslubóka og fræðimanna á að kynna sér nánar framsetningu námsefnis í stærðfræði fyrir börn, bæði efnis sem er í notkun á hverjum tíma og eldra efnis, sem var mótað eins og rétt var talið pegar pað var gefið út.

Royaumont-málpingið olli straumhvörfum í umræðu og rannsóknum á námi og kennslu í stærðfræði. Jeremy Kilpatrick, fræðimaður sem hefur lagt drjúgan skerf til rannsókna á pví sviði um margra áratuga skeið, sagði í nýlegri grein:

Fyrir tíma nýju stærðfræðinnar datt engum í hug að hugsa um skólastærðfræði sem efni sem pyrfti endurskoðunar eða endurnýjunar við; hún var einfaldlega eins og hún var. Frömuðir nýju stærðfræðinnar vissu næstum ekkert um skólanámsefni í skólastærðfræði í öðrum löndum eða jafnvel í eigin landi í sumum tilvikum. Um pað leyti sem skeiði nýju stærðfræðinnar lauk voru allir sem fengust við skólastærðfræði miklu betur að sér um pað hvað var að gerast víðsvegar um heim. (Kilpatrick, 2012, pýðing höfundar)

Gjarnan má taka undir pað með Jens Høyrup (1979) að Bundgaard-bókaflokkurinn fari nærri pví að uppfylla ítrustu kröfur stærðfræðinganna. Pví verður ekki á móti mælt að hugmyndir sem settar voru fram í Royaumont miðuðust við pað sem stærðfræðingar töldu heppilegan undirbúning undir frekara nám í stærðfræði og reikningskennsla væri grundvöllurinn. Á hinum endanum er móttakandinn, barnið. Upphaflega voru menn gagnteknir af hugmyndum Piagets um tengsl milli formgerðar hugarstarfs forskólabarna og hinnar stærðfræðilegu formgerðar sem Bourbaki-hópurinn lagði áherslu á. Sjá má skýra mynd af pví hvernig leitast er við að draga fram formgerð algebrunnar í Bundgaard-efninu. 
Markmið Royaumont-málpingsins var að skapa nýja hugsun um skólastærðfræði. Vonir voru bundnar við að rannsóknir Piagets færðu mönnum skilning á pví hvernig stærðfræðinám ætti sér stað. Рær vonir brugðust. Jafnvel mætti halda pví fram að Piaget hafi leitt endurskoðunarhreyfinguna á villigötur með pví að klæða einfaldar hugmyndir um hugsun barna í flókið táknmál sem endurómaði síðar í námsefni ungra barna. Síðar komu fram aðrir fræðimenn sem rannsökuðu stærðfræðinám. Rússneski sálfræðingurinn Lev Vygotsky (1896-1934) hafði ritað athygliverð verk um pað efni en hin fyrstu peirra birtust ekki á ensku fyrr en árið 1962 og voru ekki komin til umræðu pegar nýja stærðfræðin svokallaða var að rísa til vegs. Stærðfræðinám er flókið ferli sem fræðimenn og kennarar eru enn að glíma við að greina og skilja.

Enn má dást að hinni vönduðu og heilsteyptu framsetningu Bundgaard-námsefnisins par sem stærðfræðileg hugtök og hugmyndir eru dregin skýrum dráttum og geta nýst sem undirbúningur undir fræðilegt nám í stærðfræði. Рað var vissulega ætlun stærðfræðinganna í Royaumont pótt á barnaskólastigi skyldi pað gert óbeint. Námsefnið olli sterkum viðbrögðum á Íslandi ekki síður en 1 öðrum löndum en kveikti líka hugmyndir kennara um nýja aðkomu að og aðferðir við stærðfræðikennslu. Umræða um stærðfræðikennslu hafði að mestu legið í dvala hérlendis um áratuga skeið.

Umræða og hugmyndavinna fékk byr undir báða vængi meðal kennara í kjölfar uppnáms vegna Bundgaard-námsefnisins og leiddi til vinnu að útgáfu kennslubókaflokksins RB, Stærðfræði handa grunnskólum, á vegum Skólarannsóknadeildar Menntamálaráduneytisins og Ríkisútgáfu námsbóka áđur en útgáfu Bundgaard-bókaflokksins var að fullu lokið. Nýtt námsefni tók einnig við af RB-bókaflokknum í fyllingu tímans. Hvort tveggja er alltaf mótandi páttur: samfélagið og pekkingin. Til sérhvers tíma heyrir tilvísun námsefnis til samfélagsins og skoðana manna á framsæknum hugmyndum eins og staðan er í pann mund. Jafnframt færast menn lengra fram í leit að pekkingu og aðferðum við að nálgast hugsun og proska barnanna.

* Myndir 2, 5 og 6 með lausnum nemenda eru teknar úr bókum í einkasafni höfundar.

\section{Influences from the Royaumont-seminar in 1959 on primary school arith- metic in Iceland}

A seminar on new thinking in school mathematics was held in Royaumont, France in 1959. At the seminar, the European proponents for reform of school mathematics met representatives of the New Math movement in the United States. Some of the European participants were members of the Bourbaki-group of mathematicians who worked on presenting all mathematics in a unified modern way, mathematique moderne. One of the final recommendations of the seminar was that each country could reform its mathematics teaching according to its own needs; establishing as much cooperation as possible was recommended, however. The Nordic participants at the Royaumont Seminar agreed upon cooperation on reform of mathematics teaching and presented their ideas to governmental bodies. The issue was taken up in the Nordic Council, which decided to set up a committee under its Culture Commission. Each of four countries - Denmark, Finland, Norway and Sweden - appointed four persons to the Nordic Committee for Modernizing Mathematics Teaching, NKMM.

The Nordic Committee's task was to analyse the current situation in mathematics education, to work out curriculum plans and to write experimental texts. The committee appointed several teams of writers. The focus was on mathematical content, and the teaching of seventh to twelfth grades was its main object. However, it was decided to handle mathematics courses throughout the primary level, and for that purpose the committee contacted extra experts for the first to sixth grades of primary school. 
Writing sessions were arranged in summer 1961. Some texts were ready that autu$\mathrm{mn}$, and others were to be so successively until the beginning of 1966. A Danish author, Agnete Bundgaard, and her Finnish collaborator wrote a textbook series for the primary level. The work was translated into Icelandic and published, nearly simultaneously with its Danish publication. Denmark was one of the countries which went the furthest when it came to introducing the Bourbaki tradition into university programs, and eventually also into high school programs (Karp, 2015).

In this paper, the text of the Bundgaard textbook series in its Icelandic version is analysed with respect to presentations on arithmetic education at the Royaumont seminar, mainly by Professor Gustave Choquet, and the final recommendations of the seminar. These are compared to previous and later arithmetic textbooks in use. The questions posed concerned which ideas from the seminar were implemented in the primary level textbook series, whether the ideas were new in Iceland, and whether they survived the first wave of enthusiasm for the New Math and became a permanent contribution to school mathematics in Iceland.

The results of the comparison of the Bundgaard series with four other textbook series, two previous to it and two later ones, show that the declared intention of the reform movement to emphasise the structure of the number system and build its presentation on set-theoretical concepts was duly followed in the Bundgaard-textbook series.

The new topics in the Bundgaard series were primarily the use of set theoretical concepts and notations for building up the number concept and understanding of operations through repeated reference to the axioms of the number field, see mynd [figures] 1-11, even if negative numbers were missing. The axioms were carefully introduced with respect to structure. One can, therefore, state that the Bundgaard series went far towards meeting the mathematicians' demands. In later textbooks these concepts appeared more as aids to calculations than emphasizing structure, which gradually faded away.

Building up the system of natural numbers from prime numbers and divisibility and emphasizing mental arithmetic were revived topics that have survived in the school curriculum to this day. Approximation and estimation have also become permanent contributions to school mathematics in Iceland. What did not become permanent was replaced by an introduction to statistics and probability, discussed at Royaumont but less recommended for primary level, and by the use of variables and solving simple equations.

Key words: School mathematics - The Royaumont seminar 1959 - NKMM - Bundgaard-textbook series - School mathematics textbooks

\section{Um höfund}

Kristín Bjarnadóttir (krisbj@hi.is) er prófessor emerita við Menntavísindasvið Háskóla Íslands. Hún lauk B.A.-prófi í eðlisfræði og stærðfræði frá H.Í. 1968, kennslu- og uppeldisfræði frá H.Í. 1971, M.Sc.-námi í stærðfræði frá Oregonháskóla í Eugene 1983 og Ph.D.-gráðu í stærðfræðimenntun frá Hróarskelduháskóla 2006. Hún kenndi stærðfræði og eðlisfræði við grunnskóla og framhaldsskóla fram til 2003, og stærðfræðimenntun við Kennaraháskóla Íslands og Menntavísindasvið 2003-2013. Rannsóknaráherslur hennar varða stærðfræðikennslu og kennslubækur á grunn- og framhaldsskólastigi ásamt sögu peirra. 


\section{About the author}

Kristín Bjarnadóttir (krisbj@hi.is) is professor emerita at the University of Iceland - School of Education. She completed a BA degree in physics and mathematics at the University of Iceland in 1968, an M.Sc.-degree at the University of Oregon in Eugene in 1983, and a Ph.D.-degree in mathematics education at Roskilde University in 2006. She taught mathematics and physics at compulsory and upper secondary school levels until 2003 when she joined the University of Education, later School of Education at the University of Iceland, where she taught mathematics education. Her research interests concern mathematics teaching and textbooks for compulsory and upper secondary schools together with relevant historical aspects.

\section{Heimildir}

\section{Til greiningar}

Bundgaard, A. (1969a-1972). Sterðfreæði. Reikningur. 3a, 3b, 4a, 4b, 5a, 5b, 6, AB. Reykjavík: Ríkisútgáfa námsflokka, RN. Bundgaard, A. og Kyttä, E. (1967-1968). Stcerđfreðði. Reikningur. 1, 2a, 2b, AB. Reykjavík: RN.

Elías Bjarnason. (e.d.). Reikningsbók I - III. EB. Reykjavík: RN.

Guðbjörg Pálsdóttir. (1998). Starðfreði fyrir byrjendur: kátt er í Kynjadal. GP. Reykjavík: Námsgagnastofnun, NÁST.

Guðbjörg Pálsdóttir, Guðný Helga Gunnarsdóttir, Guðrún Angantýsdóttir og Jónína Vala Kristinsdóttir. (2002-2004). Geisli 1, 2, 3. GP. Reykjavík: NÁST.

Mogensen, A. og Balzer Petersen, S. (1999-2001). Eining 1-6. GP. Reykjavík: NÁST.

Ragnhildur Bjarnadóttir, Kolbrún Hjaltadóttir, Örn Ingólfsson, Anna Kristjánsdóttir, Anton Sigurðsson, Hanna K. Stefánsdóttir, Hörður Zóphaníasson og Ingibjörg Dorkelsdóttir. (1971-1977). Starðfraðði handa grunnskólum 1A ... 6 B. RB. Reykjavík: RN.

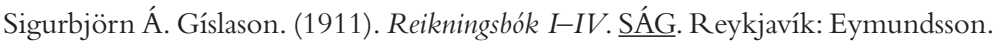

\section{Aðrar heimildir}

Allendoerfer, C. B. og Oakley, C. L. (1965). Principles of mathematics. New York: McGraw-Hill.

Anna Kristjánsdóttir. (1996). Stcerðfraðinám. Meginstefnur og viðfangsefni. Reykjavík: Kennaraháskóli Íslands.

Bundgaard, A. (1969b). Handbók kennara 3. Reykjavík: RN.

CIEAEM. (e.d.). Sótt af http://www.cieaem.org/

Elías Bjarnason. (1927-1929). Reikningsbók I-II. Reykjavík: Bókaverslun Guðm. Gamalíelssonar.

Evklíð. (1956). The thirteen books of Euclid's Elements. Ritstj. T. L. Heath. New York: Dover.

Furinghetti, F., Menghini, M., Arzarello, F. og Giacardi, L. (2008). ICMI renaissance: The emergence of new issues in mathematics education. Í M. Menghini, F. Furinghetti, L. Giacardi og F. Arzarello (ritstj.), The first century of the International Commission on Mathematics Instruction (1908-2008). Reflecting and shaping the world of mathematics education (bls. 131-147). Róm: Istituto della Enciclopedia Italiana.

Gjone, G. (1983). "Moderne matematikk" i skolen. Internasjonale reformbestrebelser og nasjonalt lareplanarbeid, I-VIII. Osló: Höfundur.

Helgi Elíasson. (1944). Lög og reglur um skóla- og menningarmál á Íslandi sem í gildi eru í marzlok 1944. Reykjavík: Fræðslumálastjórn.

Høyrup, J. (1979). Historien om den nye matematik i Danmark - en skitse. Í P. Bollerslev (ritstj.), Den ny Matematik $i$ Danmark (bls. 49-65). Kaupmannahöfn: Gyldendal.

Karp, A. (2015). Interview with Mogens Niss. The International Journal for the History of Mathematics Education, 10(1), 55-76.

Kilpatrick,J. (2012). The new math as an international phenomenon. ZDM Mathematics Education, 44, 563-571. https:// doi.org/10.1007/s11858-012-0393-2

Kristinn Gíslason. (1978). Nýja starđfraððin [óprentuð skýrsla til Fræðslustjórans í Reykjavík].

Kristín Bjarnadóttir. (2007). Mathematical education in Iceland in historical context-socio-economic demands and influences. Ph.D. dissertation nr. 456-2007. Roskilde: Roskilde Universitets Center. Sótt af http://rudar.ruc.dk/handle/1800/2914.

Kristín Bjarnadóttir. (2011). Implementing 'modern math' in Iceland - informing parents and the public. Í M. Pytlak, T. Rowland og E. Swoboda (ritstj.), Proceedings of the Seventh Congress of the European Society for Research in Mathematics Education, 9th-13th February, 2011 Rzeszów, Poland, bls. 1670-1679. Rzeszów: University of Rzeszów. Sótt af http:// www.cerme7.univ.rzeszow.pl/WG/12/CERME7 WG12 Bjarnadottir.pdf

Kristín Bjarnadóttir. (2012). „Nýja stærðfræðin“. Uppruni og afdrif. Rádstefnurit Netlu-Menntakvika 2012. Sótt af http:// netla.hi.is/menntakvika2012/009.pdf 
Kristín Bjarnadóttir. (2013). Reikningsbækur tveggja alda - markmið, markhópar og gildi. Uppeldi og menntun, 22(1), 53-76. Sótt af http://timarit.is/files/29546108.pdf\#navpanes=1\&view=FitH

Kristín Bjarnadóttir. (2017). Recommendations of the Royaumont Seminar on primary school arithmetic. Influences in the Nordic countries. Í K. Bjarnadóttir, F. Furinghetti, M. Menghini, J. Prytz og G. Schubring (ritstj.), "Dig where you stand." 4. Proceedings of the fourth International Conference on the History of Mathematics Education (bls. 47-59). Róm: Edizioni Nuova Cultura. doi:10.4458/8647

Menntamálaráđuneytið. (1960). Námsskrá fyrir nemendur á fraðsluskyldualdri. Reykjavík: Höfundur.

Menntamálaráðuneytið, skólarannsóknadeild. (1977). Um stærðfræðinám í grunnskóla skólaárið 1977-1978 [dreifibréf undirritað af Önnu Kristjánsdóttur]. Reykjavík: Höfundur.

Nordisk Råd. (1967a). Nordisk skolmatematik. (Nordisk udredningsserie, 9). Stokkhólmur: Höfundur.

Nordisk Råd. (1967b). New school mathematics in the Nordic countries. Stokkhólmur: Höfundur.

OEEC. (1961). New thinking in school mathematics. París: Höfundur.

Ólafur Daníelsson. (1927). Kenslubók í algebru. Akureyri: Bókaverslun Dorsteins M. Jónssonar.

Piaget, J. (1955). Les structures mathématiques et les structures operatoires de l'intelligence. Í L'Enseignement des mathématiques. Nouvelles perspectives, bls. 11-33. Neuchâtel og París: Delachaux og Niestlé.

Prytz, J. og Karlberg, M. (2016). Nordic school mathematics revisited. On the introduction and functionality of New Math. NOMAD, 21(1), 71-93.

Schubring, G. (2014a). The original conclusions of the Royaumont seminar 1959. The International Journal for the History of Mathematics Education, 9(1), 89-101.

Schubring, G. (2014b). The road not taken - The failure of experimental pedagogy at the Royaumont Seminar 1959. Journal für Mathematik-Didaktik, 35(1), 159-171. https://doi.org/10.1007/s13138-013-0058-x

Steingrímur Arason. (1928). Reikningsbók handa alpýduskólum (4. útgáfa endurbætt og aukin). Reykjavík: Gutenberg.

Swetz, F. J. (1992). Fifteenth and sixteenth century arithmetic texts: What can we learn from them? Science and Education, 1(4), 365-378.

Van Egmond,W. (1980). Practical mathematics in the Italian Renaissance: a catalog of Italian abbacus manuscripts and printed books to 1600. Í Annali dell'Istituto e Museo di Storia della Scienza. Monografia N. 4 (bls. 3-36). Flórens: Istituto e Museo di Storia della Scienza.

Kristín Bjarnadóttir. (2018)

Áhrif Royaumont-málpingsins 1959 á íslenskt námsefni í stærðfræði fyrir börn.

Netla - Veftímarit um uppeldi og menntun. Menntavísindasvið Háskóla Íslands.

Sótt af http://netla.hi.is/greinar/2018/ryn/09

DOI: https://doi.org/10.24270/netla.2018.9 